2014

\title{
Collective or Individual Benefits?: Measuring the Educational Benefits of Race-Conscious Admissions Programs
}

Deborah N. Archer

New York Law School, deborah.archer@nyls.edu

Follow this and additional works at: http://digitalcommons.nyls.edu/fac_articles_chapters

Part of the Civil Rights and Discrimination Commons

\section{Recommended Citation}

Archer, Deborah N., "Collective or Individual Benefits?: Measuring the Educational Benefits of Race-Conscious Admissions Programs" (2014). Articles \& Chapters. 360.

http://digitalcommons.nyls.edu/fac_articles_chapters/360 


\title{
ESSAY
}

\section{Collective or Individual Benefits?: Measuring the Educational Benefits of Race-Conscious Admissions Programs}

\author{
Deborah N. ArCher*
}

INTRODUCTION

I. THE COURT'S FOCUS ON COMMUNITY IN IDENTIFYING THE EDUCATIONAL BENEFITS OF AFFIRMATIVE ACTION

II. INCREASING PRESSURE TO FOCUS ON THE INDIVIDUAL IMPACT OF RACE-CONSCIOUS MEASURES IN STRICT SCRUTINY ANALYSIS ... 562 CONCLUSION ............................... 571

\section{INTRODUCTION}

In Fisher v. University of Texas at Austin, ${ }^{1}$ the United States Supreme Court ruled that colleges and universities could continue to consider race or ethnicity as one of several factors in an admissions policy that seeks to achieve broad diversity goals. ${ }^{2}$ Fisher followed the Court's prior ruling in Grutter v. Bollinger, which held that a policy that considers racial and ethnic diversity as one of many admissions

* Associate Dean, Professor of Law and Director of the Racial Justice Project, New York Law School. B.A., 1993 Smith College; J.D., 1996 Yale Law School. Portions of this Essay were initially included in an amicus curia brief filed in Fisher $v$. University of Texas at Austin on behalf of the National Black Law Students Association. I would like to thank Aderson François and Susan Abraham, my coauthors of the original brief, for the robust discussions and exchange of ideas that resulted in the brief and this Essay.

1. See generally Fisher v. Univ. of Tex. at Austin, 133 S. Ct. 2411 (2013) (remanding the case to the Fifth Circuit so that the University's race-conscious admissions policy could be considered using strict scrutiny).

2. Id. at 2419 . 


\section{Howard Law Journal}

factors could withstand constitutional scrutiny. ${ }^{3}$ Although the Fisher Court preserved the Grutter ruling, it nonetheless questioned whether the court below applied the appropriate degree of rigor when it reviewed the University of Texas's policy. The Court remanded the case to the United States Court of Appeals for the Fifth Circuit to determine if the methods selected by the University of Texas to promote racial and ethnic diversity were narrowly tailored to achieve the educational benefits that flow from a diverse student body under strict scrutiny analysis. ${ }^{4}$

To the relief of proponents of race-conscious admissions programs, the Fisher Court affirmed that the "educational benefits" that flow from a diverse student body are a compelling government interest under strict scrutiny analysis. ${ }^{5}$ The Court further upheld the Court of Appeals' determination that Grutter mandates "deference to the University's conclusion, 'based on its experience and expertise,' that a diverse student body would serve its educational goals." 6 The Fisher Court cautioned, however, that despite the considerable deference afforded to universities, the reviewing court must ensure that both a university's goal and implementation meet strict scrutiny. ${ }^{7}$ This means that a university must ultimately prove that the means adopted to achieve diversity is "necessary" to achieve the educational benefits of diversity, which include "a careful judicial inquiry into whether a university could achieve sufficient diversity without using racial classifications." 8 In the end, "[t]he reviewing court must ultimately be satisfied that no workable race-neutral alternatives would produce the educational benefits of diversity." 9

The Court gave little further guidance on precisely which of the several potential educational benefits of diversity are appropriate to consider. In exploring the availability of race-neutral alternatives and their effectiveness in achieving the same educational benefits as raceconscious programs, should courts focus on the benefits that inure to the larger educational community and society as a whole from having a diverse student population? Or should courts focus strictly on the

3. Grutter v. Bollinger, 539 U.S. 306, 325 (2003) (concluding that obtaining the educational benefits of diversity is a compelling state interest).

4. Fisher, $133 \mathrm{~S}$. Ct. at 2415.

5. Id. at 2419.

6. Id. (citation omitted).

7. Id. at $2419-20$.

8. Id. at 2420; see also Regents of the Univ. of Cal. v. Bakke, 438 U.S. 265, 305 (1978).

9. Fisher, 133 S. Ct. at 2420. 
"direct benefits" to individuals admitted under affirmative action programs? Past opinions of the Court have focused on the ability of affirmative action programs to transform and improve the broader educational community. But, in recent years opponents of affirmative action have redoubled their efforts to shift the focus to the impact on individual members of the community and the purported harms on the individual. This open question will be a primary source of debate as the Court revisits affirmative action. ${ }^{10}$ Indeed, as the Court sends Fisher back to the Fifth Circuit to apply strict scrutiny, the question of whether "a nonracial approach ... could promote the substantial interest about as well and at tolerable administrative expense," 11 will rely heavily on how "educational benefits" are defined. To measure the success of race-conscious admissions programs and the relative success of race-neutral alternatives, there must be some agreement on the goals.

How will the Court measure the relative success of race-neutral alternatives? Against what ultimate goal must the proponents of raceconscious policies measure the educational benefits their admissions policies are designed to achieve ${ }^{12}$ This Essay suggests that courts should continue to focus on the educational benefits of affirmative action that are shared by the entire educational community and society at large. Further, even if courts were to turn their focus to the impact that affirmative action programs have on individual beneficiaries of diversity initiatives, this Essay argues that the courts should conclude that the educational and career benefits to individuals far outweigh any purported harms to beneficiaries.

\section{THE COURT'S FOCUS ON COMMUNITY IN IDENTIFYING THE EDUCATIONAL BENEFITS OF AFFIRMATIVE ACTION}

Underpinning the Court's affirmative action opinions is the recognition that the benefits of race-conscious admissions programs are substantial and inure to many segments of society. In Fisher and its previous affirmative action opinions, the Court has placed heavy em-

10. See George R. La Noue \& Kenneth L. Marcus, "Serious Consideration" of Race-Neutral Alternatives in Higher Education, 57 CATH. U. L. REv. 991, 1002 (2008); Kenneth L. Marcus, Diversity and Race-Neutrality, 103 Nw. U. L. Rev. ColloquY 163,165 (2008) [hereinafter Marcus, Diversity and Race Neutrality].

11. Wygant v. Jackson Bd. of Educ., 476 U.S. 267, 280 n.6 (1986).

12. See Marcus, Diversity and Race-Neutrality, supra note 10 , at 166 . 


\section{Howard Law Journal}

phasis on the collective benefits of race-conscious admissions programs rather than embracing the belief that affirmative action programs are for the sole benefit of minority students who have benefitted from affirmative action. While the Court did not definitively state how it or other courts would define the educational benefits at issue, there is evidence in the Fisher opinion that the Court will focus on the broader educational benefits of affirmative action, as opposed to the benefits to any particular student. The Court acknowledged that a racial and ethnically diverse student body enhances classroom dialogue and lessens racial isolation and the use of racial stereotypes. ${ }^{13}$ Additionally, the Court focused on a university's unique First Amendment rights and the importance of giving universities the flexibility to "provide that atmosphere which is most conducive to speculation, experiment, and creation" for all of its students. ${ }^{14}$

These elements of the Court's opinion are consistent with the Court's past treatment of affirmative action programs and a conclusion that minority students are not the sole intended beneficiaries of race-conscious admissions programs. Indeed, the Court has indicated that the primary purpose of race-conscious admissions policies is to provide the myriad benefits of a diverse learning environment to the larger educational community, and in fact to society as a whole. Among the benefits recognized by courts has been the promotion of " 'cross-racial understanding,' 'break[ing] down racial stereotypes,' enabl[ing] students to better understand persons of other races, better prepar[ing] students to function in a multi-cultural workforce, cultivat[ing] the next set of national leaders, and prevent[ing] minority students from serving as 'spokespersons' for their race."15 In Grutter, the Court recognized the additional benefits of better enabling students to understand people of different races and better preparing students to be professionals. ${ }^{16}$

In concluding that institutions of higher education have a compelling interest in creating a racially and ethnically diverse student body to advance their educational goals, the Court in Grutter implicitly recognized that those benefits should redound to the classroom. Grutter not only affirmed a university's interest in attaining a diverse student

13. Fisher, 133 S. Ct. at 2418.

14. Id. (quoting Sweezy v. New Hampshire, 354 U.S. 234, 263 (1957)).

15. Fisher v. Univ. of Tex. at Austin, 631 F.3d 213, 230 (5th Cir. 2011), vacated, 133 S. Ct. 2411 (2013); see also Grutter v. Bollinger, 539 U.S. 306, 330 (2003); Regents of the Univ. of Cal. v. Bakke, 438 U.S. 265, 314 (1978).

16. Grutter, 539 U.S. at 330. 
body, but also recognized the paramount educational benefits that flow from a diverse classroom, as opposed to simply having diversity on the college campus generally. ${ }^{17}$ In discussing the importance of diversity, Justice O'Connor stressed the importance of "cross-racial understanding" and classroom discussions that are "livelier, more spirited, and simply more enlightening and interesting" because of the existence of diversity in and outside of the classroom. ${ }^{18}$

Similarly, in Bakke, Justice Powell emphasized the importance of a university's pursuit of the "robust exchange of ideas which discovers truth 'out of a multitude of tongues" "19 and the creation of an "atmosphere of 'speculation, experiment and creation'-so essential to the quality of higher education." 20

Courts have also supported educational institutions' recognition that the benefits of diversity go beyond the immediate learning environment, to embrace the role of colleges and universities to train diverse future leaders. The courts have responded to the "national consensus among university, business, and military leaders on the value of racial inclusiveness" 21 and the belief that "[i]n order to cultivate a set of leaders with legitimacy in the eyes of the citizenry, it is necessary that the path to leadership be visibly open to talented and qualified individuals of every race and ethnicity."22

17. See generally id., at 328-30 (discussing the benefits universities derive from having diverse student bodies).

18. Id. at 330 (quoting Petition for Writ of Certiorari at 246a, 244a, Grutter v. Bollinger, 288 F.3d 732 (6th Cir. 2002) (No. 02-241)).

19. Bakke, 438 U.S. at 312 (quoting United States v. Associated Press, 52 F.Supp. 362, 372 (S.D.N.Y. 1943)).

20. Id. The importance of classroom diversity has long been recognized in the context of K-12 education. See, e.g., Parents Involved in Cmty. Sch. v. Seattle Sch. Dist. No. 1, 551 U.S. 701,799 n.3 (2007) (Stevens, J., dissenting) ("[C]hildren of all races benefit from integrated classrooms . . ."); Plyler v. Doe, 457 U.S. 202, 223 (1982) (noting public education is a "principal instrument in awakening the child to cultural values, in preparing him for later professional training, and in helping him to adjust normally to his environment."); Washington v. Seattle Sch. Dist. No. 1, 458 U.S. 457, 472 (1982) ("[W]hite as well as Negro children benefit from exposure to 'ethnic and racial diversity in the classroom." "); Columbus Bd. of Educ. v. Penick, 443 U.S. 449,486 n.5 (1979) (Powell, J., dissenting) ("It is essential that the diverse peoples of our country learn to live in harmony and mutual respect. This end is furthered when young people attend schools with diverse student bodies.").

21. Lani Guinier, Admissions Rituals as Political Acts: Guardians at the Gates of Our Democratic Ideals, 117 HARv. L. Rev. 113, 122 (2003); see also Grutter, 539 U.S. at 330-31 (citing to briefs in support of the benefits of race-conscious admissions programs).

22. Grutter, 539 U.S. at 332. 


\section{INCREASING PRESSURE TO FOCUS ON THE INDIVIDUAL IMPACT OF RACE-CONSCIOUS MEASURES IN STRICT SCRUTINY ANALYSIS}

Despite the guidance from the Court, not everyone is convinced that collective measures are the appropriate means to gauge the educational benefits of affirmative action programs. First, some assert that such collective measures are pretextual and mask the true motivations behind affirmative action programs. ${ }^{23}$ Instead, some advocate that "the focus should be on the extent to which various diversity programs are able to translate educational strategies . . . into ultimate goals" and demonstrable educational attainment for individual students. ${ }^{24}$

Opponents of affirmative action have often resorted to a focus on the individual impact of affirmative action programs to undermine a program's legitimacy and acceptance. However, in the past, opponents of affirmative action have primarily focused on the purported harms that race-conscious programs caused to "innocent third parties," such as unsuccessful white applicants. ${ }^{25}$ Today, an increasing number of opponents of race-conscious admissions programs have advocated measuring the educational benefits of race-conscious admissions programs by their impact on the individual educational achievements and experiences of those admitted under those programs. ${ }^{26}$ They argue, for example, that if the Supreme Court permits affirmative action because of the educational benefits of diversity, the

23. See Marcus, Diversity and Race-Neutrality, supra note 10, at 168. See generally Richard Sander, A Systemic Analysis of Affirmative Action in American Law Schools, 57 S TAN. L. REv. 367 (2004) (arguing that affirmative action actually harms its beneficiaries by not identifying students who will perform well in law school, which leads to many black students struggling academically).

24. See Marcus, Diversity and Race-Neutrality, supra note 10 , at 168.

25. See, e.g., Grutter, 539 U.S. at 373 (2003) (Thomas, J., dissenting) ("The majority of blacks are admitted to the [University of Michigan] Law School because of discrimination, and because of this policy all are tarred as undeserving."). See generally Goodwin Liu, The Causation Fallacy: Bakke and the Basic Arithmetic of Selective Admissions, 100 MicH. L. REV. 1045 (2002) (arguing that opponents of affirmative action greatly exaggerate the unfairness and harm to white applicants that race-conscious admissions programs cause); Thomas Ross, Innocence and Affirmative Action, 43 VAND. L. REV. 297 (1990) (defining and tracing the history of the "rhetoric of innocence" relied upon by opponents of affirmative action).

26. See Ashely M. Hibbet, The Enigma of Stigma: A Case Study on the Validity of the Stigma Arguments Made in Opposition to Affirmative Action Programs in Higher Education, 21 Harv. BlackLetter L. J. 75, 76-77 (2005); Marcus, Diversity and Race-Neutrality, supra note 10, at 168; Angela Onwuachi-Willig, et. al, Cracking the Egg: Which Came First-Stigma or Affirmative Action?, 96 CALIF. L. REV. 1299, 1301-02 (2008). 
only appropriate measure is the ability of the admissions program to achieve educational benefits for individuals. ${ }^{27}$

The most widespread of these arguments has focused on the alleged "mismatch" that occurs when minority students attend top-tier educational institutions. ${ }^{28}$ Mismatch theory faults race-conscious admissions programs for inflicting "significant academic harm" on minority students. ${ }^{29}$ According to this theory, mismatch happens when a "student finds herself in a class where she has weaker academic preparation than nearly all of her classmates" and falls behind. ${ }^{30}$ Under mismatch theory, most black students do not belong in elite institutions and are better off at less competitive institutions, where their alleged academic mismatch is less pronounced. Mismatch theory has been most aggressively pushed in the context of admissions to "elite" law schools. ${ }^{31}$ In his article about mismatch theory, Professor Richard Sander argues that we would see an increase in the number of black students who graduate from law school and pass the bar examination if affirmative action programs were eliminated. ${ }^{32}$ This increase, according to Professor Sander, would result because black students would attend less competitive law schools where they would be able to compete more effectively. ${ }^{33}$

The argument that race-conscious admissions programs do not provide "educational benefits" because affirmative action vioiates the "fundamental legal premise" 34 for permitting race-conscious admissions-helping minority students-is both legally and factually incorrect. As discussed earlier in this Essay, race-conscious admissions programs are for the educational benefit of every member of the academic community, not only for minority students. Furthermore, the assertion that affirmative action programs have no educational benefit because minority students end up attending schools that are too academically challenging for them is factually incorrect and inappropriately seeks to displace minority students' independent, informed

27. Marcus, Diversity and Race-Neutrality, supra note 10, at 168.

28. See Richard Sander \& Stuart Taylor, Jr., Mismatch: How Affirmative ACTion Hurts Students It's Intended to Help, AND Why Universities Won't Admit It 3-4 (2012).

29. Id. at 3.

30. Id. at 4 .

31. See Sander, supra note 23, at 453.

32. Id. at 474-77.

33. Id.

34. Brief for Neither Party at 9-10, Fisher v. Univ. of Tex. at Austin, 133 S. Ct. 2411 (2013) (No. 11-345). 
judgment about the potential costs and benefits of attending flagship universities and top-tier graduate schools. The choice to stretch and challenge themselves academically at top-tier schools in exchange for the academic opportunities and the potential of increased career opportunities is a valuable one that race-conscious admissions programs have made possible. The ability to make these choices for themselves should not be taken away because of a misplaced focus on educational benefits. As minority students make selections about their education and work to become legal professionals, they make choices about which law school to attend by engaging in their own cost-benefit analysis, which goes beyond potential GPA and class rank.

Educational and placement benefits are undoubtedly a large part of why students of all races, creeds, and colors fight so hard to get into top schools. As important as these benefits are, however, they fail to capture anything approaching the full value of attending an elite law school. In addition to acquiring substantive knowledge and gaining preferential initial access to the employment market, students attending elite schools are also socialized into the habits and possibilities of eliteness and granted a lifetime membership in the elite networks to which the graduates of such institutions automatically belong. ${ }^{35}$

If courts choose to ignore Supreme Court precedent indicating a focus on the collective educational benefits of affirmative action and adopt a measure that focuses on the individual students who benefit from race-conscious admissions programs, the evidence will establish that individual benefits do inure to minority students who attend elite and selective educational institutions that employ race-conscious admissions programs. ${ }^{36}$ For example, despite statistics indicating that black law students often achieve lower-than-average GPAs and bar passage rates, ${ }^{37}$ the fact is that most black law students go on to be

35. David B. Wilkins, A Systematic Response to Systemic Disadvantage: A Response to Sander, 57 Stan. L. Rev. 1915, 1931 (2005).

36. In addition to focusing on the individual educational benefits to minority students, a court would necessarily have to focus on the individual educational benefits white students get from being educated in a racially and ethnically diverse environment.

37. While reports that black law students fail the bar examination at higher rates than other law school graduates are cause for concern, these reports are not entirely useful without information regarding which state bar examinations were taken and adjustments for the difficulty of each state bar. Moreover, there is evidence that the disparity in bar pass rates is not attributable to affirmative action. See generally Daniel E. Ho, Why Affirmative Action Does Not Cause Black Students to Fail the Bar, 114 YALE L. J. 1997 (refuting the claim that affirmative action causes blacks to fail the bar). There are several reasons for the disparity in educational outcomes for minority students and some of these reasons would only be made worse by getting rid of affirmative action, decreasing diversity and increasing racial isolation. To assess the impact of race- 
lawyers. ${ }^{38}$ That some black students graduate in the bottom half of their class or may not pass the bar examination on their first attempt does not negate the value of the high-quality legal education they received. To the contrary, their legal education will continue to be valuable to them as they pursue legal and law-related careers. ${ }^{39}$ In addition to substantive legal knowledge, the students have gained credentials that employers value and relationships and skills that will serve them throughout their law-related careers. ${ }^{40}$ Considering these potential benefits, it is hard to believe that the black students who currently graduate from law school, even if they are not at the top of their class, would have been better off had they not been accepted into law school at all. ${ }^{41}$

Rather than misguiding minority law students, race-conscious admissions programs allow many a valuable opportunity to attend a toptier, highly ranked law school. While their test scores and GPAs may be below the average as compared to other admitted students, their legal careers are not undermined by the choice they made to pursue this opportunity. For example, in a study of the post-graduate success of minority graduates of the University of Michigan Law School, Richard O. Lempert, David L. Chambers and Terry K. Adams found that LSAT scores and undergraduate GPAs do not predict the future career success of minority students. ${ }^{42}$ Despite the lower LSAT scores and undergraduate GPAs of many minority students admitted to the University of Michigan Law School, these students went on to achieve levels of career success that met or surpassed the levels achieved by their white classmates. ${ }^{43}$ Moreover, the study found that law school

conscious admissions programs on minority students, courts must first acknowledge and address several critical factors that contribute to minority underperformance in the classroom, including racial discrimination, stereotype threat and segregated and inadequate $\mathrm{K}$ through 12 education systems. "Race continues to structure the opportunities and outlook of all Americans even as overt discrimination based on race recedes. Any dialogue about affirmative action, or about legal education and practice generally, must candidly acknowledge this complex reality." Wilkins, supra note 35, at 1961.

38. Timothy T. Clydesdale, A Forked River Runs Through Law School: Toward Understanding Race, Gender, Age, and Related Gaps in Law School Performance and Bar Passage, 29 LAw \& Soc. INQuiRy 711, 727 (2004).

39. Although the recession and the resulting economic realities have negatively impacted the job market and the market for legal services, there is continuing value in a legal education as law schools provide valuable training and credentials that prepare their students for legal and law-related careers.

40. See Wilkins, supra note 35, at 1943-44.

41. See id. at 1931 .

42. David L. Chambers et al., Michigan's Minority Graduates in Practice: The River Runs Through Law School, 25 LAw \& Soc. INOUIRY 395, 397, 401 (2000).

43. Id. at 496. 


\section{Howard Law Journal}

grades explain less than five percent of the variance in income across the students in the sample. ${ }^{44}$ Accordingly, a decision to eliminate race-conscious admissions programs should not rest on the perceived impact of the credentials of entering minority students or the fact that many black law students do not graduate at the top of their class, when those factors have not been found to predict future success.

Far from impeding their future achievements, the choices that black students are making about which law schools to attend have led them to success, individually and for their broader communities. It is not disputed that black graduates of top-tier law schools overwhelmingly complete law school and go on to pass the bar. Indeed, over ninety-five percent of blacks attending the most elite schools graduate. ${ }^{45}$ And while many black students are not graduating in the top of their law school classes, race-conscious admissions programs at the undergraduate and graduate level help black students overcome systemic barriers that previously blocked their entrance to our nation's flagship colleges and universities, creating pipelines to higher education and impressive and influential careers. ${ }^{46}$

Black students at top-tier institutions, in fact, graduate at high rates and move on to have careers as distinguished and accomplished as their white classmates. ${ }^{47}$ In Crossing the Finish Line: Completing College at America's Public Universities, the authors found a strong positive relationship between graduation rates and the selectivity of the educational institution. ${ }^{48}$ The authors also directly challenged the assumption that "mismatching" led to lower graduation rates for black students. In their study, the authors grouped black men by their high school GPAs and then examined whether those with relatively low GPAs who enrolled in more selective public universities graduated at lower rates than those with the same GPAs who attended less selective institutions. The results proved just the opposite. To illustrate, of

44. See id. at 501.

45. See Wilkins, supra note 35 , at 1927 n.43.

46. See generally David B. Wilkins, Rollin' on the River: Race, Elite Schools, and the Equality Paradox, 25 LAw \& Soc. INQuiRy 527 (2000) (introducing the "equality paradox" concept and discussing how graduating from a prestigious institution is "the most important determinant" of the future success of minorities).

47. See William G. Bowen \& Derek Bok, The Shape of the River: Long-Term ConSequences of Considering Race in College and University Admissions at 55-57 (1998) [hereinafter BowEN \& BOK, THE SHAPE OF THE RIVER] (discussing the matriculation rates of underrepresented minorities); see also Chambers et al., supra note 42, at 397, 401.

48. William G. Bowen et al., Crossing the Finish line: Completing College at AmericA's Public Universities at 192, 193 fig.10.1 (2009) [hereinafter Bowen et AL., CrossING THE FINISH LINE]. 
the students with high school GPAs below 3.0, those who went to the most selective colleges and universities in the study had a graduation rate six percentage points higher than those who went to second-tier schools and eight percentage points higher than those who went to third-tier schools. ${ }^{49}$ Indeed, for all GPA levels, black men who went to more selective institutions graduated at higher rates than their peers with similar grades who went to less selective colleges. ${ }^{50}$

Moreover, contrary to what the overmatch or mismatch hypothesis would lead us to expect, the relative graduation rate advantage associated with going to a more selective university was even more pronounced for black men at the lower end of the high school grade distribution than it was for students with better high school records. $^{51}$

The findings of several studies also directly refute any claim that black students would fare better academically at schools where the average SAT score was similar to their own scores. The study found that the black students in the lowest category of SAT scores graduated at higher rates the more selective the school they attended.52 Moreover, for students of similar gender, socioeconomic status, high school grades and SAT scores, graduation rates were highest for those students who attended the most selective schools. ${ }^{53}$ Finally, students in the same category of SAT scores were more likely to ultimately earn an advanced degree the more selective the school they attended. ${ }^{54}$ This was true even if the student received a lower GPA at the more prestigious school..$^{55}$

These studies support the conclusion that to help improve the academic and professional outcomes for minority students we should not "discourage them from enrolling in academically strong programs that choose to admit them. On the contrary, [they] should be encouraged to 'aim high' when deciding whether and where to pursue educational opportunities beyond high school."56 Indeed, the problem of "undermatching," where students with strong academic credentials do not enroll in colleges or universities that match their academic

49. Bowen et al., Crossing the Finish Line, supra note 48, at 209.

50. Id.

51. Id.

52. See Bowen \& Bok, The Shape of the River, supra note 47, at 61, 259; Bowen et AL., Crossing THE Finish Line, supra note 48, at 209.

53. Bowen \& Bok, The Shape of the River, supra note 47, at 63, 259.

54. Id. at 114.

55. Id.

56. Bowen et Al., Crossing the Finish Line, supra note 48, at 211. 


\section{Howard Law Journal}

credentials, is far more troubling for minority students than the alleged issue of mismatch advanced in the Sander Brief. ${ }^{57}$ A study of undermatching conducted by the authors of Crossing the Finish Line found that a disproportionate number of undermatches are among racial and ethnic minorities, with it being more common among black students. ${ }^{58}$ The issue of undermatching is highly connected to the issue of diversity and race-conscious admissions programs because one reason students often fail to attend colleges and universities that match their academic credentials is their belief that, because of their race, they would be "uncomfortable" in that community. ${ }^{59}$

In addition to the clear benefits to the educational and career opportunities for blacks brought about by race-conscious admissions programs, the individual harms that were feared would befall minority students under these programs have not come to pass. A prominent and long-standing criticism of affirmative action programs is that minority students will experience "internal" and "external" stigma, both doubting their own abilities and merit and having their fellow students assume they were admitted because of their race and not their qualifications. $^{60}$ If race-conscious admissions programs in fact cause external or internal stigma for minority students, one would assume that minority students enrolled at colleges and universities in states that have banned race-conscious admissions programs would not experience this stigma. Or, that the stigma experienced by these students would be less than the stigma experienced by students attending schools on campuses actively employing race-conscious admissions programs. Yet, no causal connection between race-conscious admissions programs and racial stigma has ever been established. In fact, recent studies have discounted any role of race-consciousness in promoting racial stigma on college and university campuses. Rather, students attending schools in states banning the consideration of race are likely to find themselves in unwelcoming environments, and are more likely to encounter racial hostility and stigma. In many respects, they are not faring as well as their counterparts attending schools that em-

57. See id. at 100 .

58. Id. at 103 .

59. See id. at 104.

60. In fact, those who argue that race-conscious admissions programs should be banned because they stigmatize minority students are only aiding racial discrimination. Stamping all minority students with "badge[s] of inferiority" by assuming they lack qualifications is itself racial discrimination. See André Douglas Pond Cummings, The Associated Dangers of "Brilliant Disguises," Color-Blind Constitutionalism, and Postracial Rhetoric, 85 IND. L.J. 1277, 1282 (2010). 
brace the value of racial diversity and employ race-conscious admissions programs.

In one study of the experiences of minority students currently enrolled in undergraduate and graduate programs in the "hard sciences," the author found that minority students in states that allow the use of race-conscious admissions programs experience far less stigma than students in states that have banned racial considerations. ${ }^{61}$ First, the study confirms that overt acts of racism by students continue on college and university campuses, in fact, occurring twice as often on campuses in the four states in which the consideration of race has been banned. ${ }^{62}$ Furthermore, the study suggests that in states where race-consciousness is banned, minority students are the victims of stigmatization more often than students attending school on campuses openly practicing race-conscious admissions. ${ }^{63}$ Contrary to what opponents of race-conscious admissions have argued, the consideration of race may in fact help reduce the racial stigma suffered by minority students, not produce it.

Finally, the study suggests that increased racial diversity, not less, may help to alleviate feelings of stigma. Racial isolation on campuses may increase feelings of internal and external stigma, as minority students who have been the sole minority student in a course experience more stigma "than do their counterparts who have taken no classes in which they were the sole minority student." 64 Unsurprisingly, minority students enrolled in schools in states that have banned race-conscious admissions programs were disproportionately more likely to attend classes in which they were the sole minority student. ${ }^{65}$ Indeed, the study found that $68.6 \%$ of students who attended school in states that banned the consideration of race in admissions decisions had one or more classes in which they were the sole minority student. ${ }^{66} \mathrm{Mi}$ nority students who were the lone minority student in a class experienced overt racism from other students at a rate of four times as often as students who have never taken a class in which they were the only

61. See Deirdre M. Bowen, Brilliant Disguise: An Empirical Analysis of a Social Experiment Banning Affirmative Action, 85 IND. L.J. 1197, 1198-99, 1215 n.101 (2010). Four states included in the study - California, Washington, Florida, and Michigan-have banned race-conscious admissions programs. $I d$. at $1217-18$. Twenty-three other states and two territories where affirmative action is allowed were also included in the study. Id. at 1218 .

62. Id. at 1222 tbl.2.

63. Id. at 1224 .

64. Id. at 1229 .

65. Id. at 1227 .

66. Id. at 1227 tbl. 4 . 


\section{Howard Law Journal}

minority, ${ }^{67}$ and "encountered racism from faculty at twice the rate of students who have never found themselves as the lone minority in the classroom." $" 68$

In another study, white and minority students at seven upper-tier public law schools were surveyed to explore ${ }^{69}$ whether racial stigma would dissipate if race-conscious programs were eliminated. ${ }^{70}$ The study compared the survey responses of students who attended educational institutions that employed affirmative action with responses of students who attended institutions that prohibited the use of affirmative action, ${ }^{71}$ and sought to examine the impact of affirmative action on the "internal thoughts and feelings of minority law students while in school." 72

The study found that there was no statistically significant difference in feelings of stigmatization for minority students who attended schools with or without race-conscious programs. ${ }^{73}$ The majority of students in both groups reported that classmates and teachers did not treat them differently because of affirmative action related stigma. ${ }^{74}$ Interestingly, students who attended schools that did not employ raceconscious admissions programs were "more likely to agree that law schools should make special efforts to overcome past discrimination and that the benefits of affirmative action outweigh the costs."75

The fact remains, the root causes of racial stigma reach back much further than race-conscious admissions programs. Minority students faced racial stigma on college campuses long before the use of these programs and that stigma will continue without these programs. ${ }^{76}$ Not only do the alleged harms of race-conscious admissions programs not outweigh their documented benefits, there is no proof that those harms exist at all. Minority students are less likely to suffer

67. Id. at $1228-29,1230 \mathrm{tbl} .6$.

68. Id. at 1229 .

69. The law schools included in this survey were the University of California, Berkeley; the University of California, Davis; the University of Cincinnati; the University of lowa; the University of Michigan; the University of Virginia and the University of Washington. Onwuachi-Willig et al., supra note 26 , at 1304 .

70. See id. at 1305.

71. Id.

72. Id.

73. Id. at 1331 tbl.2, 1332.

74. Id. at 1332-33.

75. Id. at 1334 .

76. See generally R. A. Lenhardt, Understanding the Mark: Race, Stigma, and Equality in Context, 79 N.Y.U. L. Rev. 803, 816-23 (2004) (discussing the work of social scientist Erving Goffman, who is most notable for his research surrounding "the problem of racial stigma"). 
from stigmatization where they are part of a critical mass of minority students, often made possible through the use of race-conscious admissions programs. ${ }^{77}$ Concerns about the impact of racial stigma, therefore, weigh in favor of expanding race-conscious admissions programs, not decreasing or abolishing them.

\section{CONCLUSION}

The Supreme Court has now repeatedly held that race-conscious admissions programs in public colleges and universities are constitutional and have significant educational benefits that flow to all members of the academic community and our larger society. In evaluating whether a particular race-conscious admissions program is narrowly tailored under strict scrutiny analysis, courts should continue to focus on the myriad benefits such programs provide to all members of the community. That opponents of affirmative action continue to argue that these programs undermine minority students' educational achievement by exposing them to stigma and academic environments in which they are outmatched does not undermine this analysis. The gap between the performance of minority and white students is quite troubling, but race-conscious admissions programs cannot be faulted for those troubles nor do those gaps negate the collective and individual benefits of affirmative action.

77. Walter R. Allen \& Daniel Solorzano, Affirmative Action, Educational Equality and Campus Racial Climate: A Case Study of the University of Michigan Law School, 12 Berkeley LA RAZA L.J. 237, 260, 299-301 (2001). 
